\title{
Occurrence of Fungal Pathogens and Mycelial Compatibility among Sclerotinia spp. Associated with Jerusalem Artichoke in Turkey
}

\author{
Göksel Özer ${ }^{1}$ and Harun Bayraktar ${ }^{2 *}$ \\ ${ }^{1}$ Department of Plant Protection, Faculty of Agriculture and Natural Sciences, Abant İzet Baysal University, Bolu, Turkey \\ ${ }^{2}$ Department of Plant Protection, Faculty of Agriculture, Ankara University, Ankara, Turkey \\ *For correspondence: bayrakta@agri.ankara.edu.tr; harunbayraktar@hotmail.com
}

\begin{abstract}
The occurrence of fungal pathogens was surveyed in Jerusalem artichoke fields in Ankara province, Turkey during 2011-2012 years. A total of 106 isolates were collected from diseased plant samples. Isolates were identified as Sclerotinia sclerotiorum, S. minor, Macrophomina phaseolina, Golovinomyces cichoracearum, Fusarium oxysporum and F. equiseti. Morphological identification was confirmed by DNA sequencing and species-specific PCR assay. Sclerotinia wilt/rot disease caused by $S$. minor and S. sclerotiorum was the most common disease limiting Jerusalem artichoke production of Turkey. To our knowledge, S. minor, M. phaseolina, G. cichoracearum have been detected in Jerusalem artichoke fields in Turkey for the first time. Isolates of $S$. minor and $S$. sclerotiorum were also characterized for their aggressiveness and mycelial compatibility groups (MCGs). In pathogenicity test, $S$. sclerotiorum was observed to be more pathogenic than $S$. minor in this crop. 29 S. sclerotiorum isolates were classified into 16 MCGs while $64 \mathrm{~S}$. minor isolates grouped into $7 \mathrm{MCG}$. This study is the first comprehensive study on the characterization of fungal pathogens associated with Jerusalem artichoke in Turkey. (C) 2015 Friends Science Publishers
\end{abstract}

Keywords: Jerusalem artichoke; Fungal pathogens; Sclerotinia spp.; MCGs

\section{Introduction}

Jerusalem artichoke (Helianthus tuberosus) is a species of sunflower native to eastern North America. It is cultivated as a vegetable, fodder crop in many countries. Jerusalem artichoke tubers are an important source of insulin for diabetics. The aboveground parts of Jerusalem artichoke are used making alcohol for industry and as animal feed. Also, wild Jerusalem artichoke accessions are used in breeding programs for incorporating traits into cultivated sunflowers (Kays and Nottingham, 2007). The cultivation of Jerusalem artichoke in Turkey is mainly performed in Ankara province, accounting for approximately $92 \%$ of the total production (TUIK, 2013).

Occurrence of fungal diseases is the principle factor limiting the production potential of Jerusalem artichoke. The major diseases of this crop are sclerotinia wilt/rot caused by Sclerotinia sclerotiorum and $S$. minor, rust by Puccinia helianthi, southern wilt/blight/collar rot by Sclerotium rolfsii and powdery mildew by Golovinomyces cichoracearum (Syn: Erysiphe cichoracearum). Sclerotinia is an important disease in Europe, while rust and southern wilt pathogens cause the important diseases in North American. Powdery mildew is a less important disease in this crop (Kays and Nottingham, 2007). Other fungi such as
Botrytis cinerea, Macrophomina phaseolina, Fusarium spp., Rhizoctonia solani, Rhizopus spp. and Phoma exigua have been obtained from diseased tissues of Jerusalem artichoke (Gulya and Masirevic, 1991; Kays and Nottingham, 2007). Very little information is known about diseases on Jerusalem artichoke in Turkey. Among the fungi species, $S$. sclerotiorum and Puccinia helianthi were detected in this crop in Turkey (Bremer, 1954).

S. sclerotiorum and $S$. minor are the important plant pathogenic species that cause severe yield losses in a wide range of economically important plants, including vegetables, field crops and flowers (Agrios, 2005). Disease symptoms include darkening of leaves, soft and watery necrotic tissues covered with a whitish mycelium, dark sclerotia on stem, and eventually wilted and died of infected plants (Kays and Nottingham, 2007). Both species can be distinguished from each other based on their sclerotia characteristics (Agrios, 2005). Mycelial compatibility groups (MCGs) testing is a useful method to provide the identification of genetically distinct individuals within Sclerotinia populations (Kohn et al., 1990, 1991). The members of the same MCG produce one confluent colony without reaction line while mycelial incompatibility is characterized by the formation of a barrage of dead cells between the two incompatible colonies (Kohn et al., 1990). 
Many studies have been performed for detecting genetic variability within the populations of $S$. sclerotiorum and $S$. minor in different hosts (Degener et al., 1999; Mert-Türk and Mermer, 2004; Wu and Subbarao, 2006; Yanar and Onaran, 2011; Karimi et al., 2012). There was no information about the population structure of Sclerotinia species, causing yield losses in Jerusalem artichoke.

The aim of this study was to identify fungal pathogens associated with Jerusalem artichoke production of Turkey and characterize the populations of $S$. sclerotiorum and $S$. minor based on pathogenicity and mycelial compatibility grouping tests. The results will contribute to the development of disease management methods to control these pathogens.

\section{Materials and Methods}

\section{Fungal Isolates}

Disease surveys were performed on different Jerusalem artichoke fields located in Ankara province, the major production area of Turkey during 2011-2012 years. The plant samples with the symptoms of disease were collected from different areas of each field. Isolation of wilt and rot pathogens was carried out by placing surface-sterilized infected tissues in Petri dishes containing potato dextrose agar (PDA) medium. The cultures were incubated for 7 days at $23^{\circ} \mathrm{C}$ in a $12 \mathrm{~h}$ dark/light cycle. Pure cultures obtained through single hyphal tip method were maintained on PDA medium at $8^{\circ} \mathrm{C}$. The isolates were identified based on morphological characteristics described by Domsch et al. (1980), Tariq et al. (1985) and Leslie and Summerell (2006). For the identification of powdery mildew infections, conidiophores and conidia were stripped off the leaf surface and examined using a light microscope. Identification of powdery mildew disease was performed based on microscopic structures described by Braun (1987) and Cho et al. (2012).

\section{Molecular Identification}

Genomic DNA was isolated from mycelial mats of isolates scraped from the surface of PDA medium according to the minipreparation method of Edel et al. (2000). Fungal mycelia of each isolate were homogenized in liquid nitrogen and suspended in $500 \mu \mathrm{L}$ of extraction buffer $(50 \mathrm{mM}$ Tris$\mathrm{HCl} \mathrm{pH}: 7.5,50 \mathrm{mM}$ EDTA, 3\% SDS). The DNA was twice extracted with phenol/chloroform/isoamylalcohol and precipitated by addition of 0.5 volume of $7.5 \mathrm{M}$ ammonium acetate and 1.5 volume of isopropanol. The resultant DNA pellet was washed with ethanol, dissolved in $\mathrm{ddH}_{2} \mathrm{O}$, and stored at $-20^{\circ} \mathrm{C}$. DNA extraction from fungal structures of powdery mildew collected from leaf surface was carried out using the DNeasy Plant Mini Kit (Qiagen) according to manufacturer's instructions.

The rDNA-ITS (internal transcribed spacer) region of representative isolate of each fungi species was amplified by polymerase chain reaction with primers ITS1/4 (White et al., 1990). PCR reaction was performed in $50 \mu \mathrm{L}$ reaction volume containing 10x assay buffer, $1.5 \mathrm{mM}$ of $\mathrm{MgCl}_{2}, 0.4$ $\mu \mathrm{M}$ of each primer, $0.2 \mathrm{mM}$ of dNTPs, 1.5 unit of Taq DNA polymerase (MBI, Fermentas) and remaining deionized water. DNA amplification was performed in a thermal cycler with the following temperature profiles: one cycle of $94^{\circ} \mathrm{C} 1 \mathrm{~min}, 35 \mathrm{cycles}$ of $94^{\circ} \mathrm{C} 30 \mathrm{sec}, 57^{\circ} \mathrm{C} 30 \mathrm{sec}, 72^{\circ} \mathrm{C} 1$ min, and $10 \mathrm{~min}$ at $72^{\circ} \mathrm{C}$. ITS region of powdery mildew was amplified using the annealing step at $52^{\circ} \mathrm{C}$ and primers ITS5 (White et al., 1990) and P3 (Kusaba and Tsuge, 1995) according to above PCR protocol.

The amplified DNA products were sequenced in both directions using the same primers at Refgen Biotechnology Laboratory (Ankara, Turkey). The resulting sequences were examined by BLAST analysis using the NCBI website.

The identification of Sclerotinia species was also confirmed by species-specific PCR assay based on novel laccase gene sequence (Hirschhäuser and Fröhlich, 2007). The primer MP-SmF/MP-UniR and MP-SsF/MP-UniR were used for identification of $S$. minor and S. sclerotiorum, respectively. The PCR amplification was performed using the method of Hirschhäuser and Fröhlich (2007). PCR product was electrophoresed in a $1.4 \%$ agarose gel, which was then stained with ethidium bromide for observation of the amplicons.

\section{Pathogenicity Tests}

The aggressiveness of Sclerotinia species to Jerusalem artichoke was tested with the method described by Irani $e t$ al. (2011). Seed tubers were disinfected by immersion in sodium hypochlorite $(1 \% \mathrm{NaOCl})$ for $3 \mathrm{~min}$, rinsed twice in distilled water and grown in $20 \mathrm{~cm}$ in diameter plastic pots for 21 days. The top part of the main stem was severed with a razor blade and inoculated with a agar disc placed into a $1000 \mu \mathrm{L}$ pipette tip. The inoculated plants were grown at $23^{\circ} \mathrm{C}$ for 7 days with a $12 \mathrm{~h}$ dark/light cycle and evaluated for lesion length (cm) on the main stem (Irani et al., 2011). Pathogenicity assays of M. phaseolina and Fusarium spp. isolates were performed by soil-inoculation method of Nene and Haware (1980). Five agar disks from each isolate grown on PDA medium were placed on the mixture of sterilized sand:corn meal and incubated for 15 days. Seed tubers were sown in $20 \mathrm{~cm}$ pots, containing the inoculated mixture and grown for 40 days. All plants were evaluated for disease symptoms. Three replicate pots were used for each the isolate. Variation in the aggressiveness of $S$. minor and $S$. sclerotiorum isolates was analyzed using analysis of variance (MSTAT, Michigan State Univ., USA) and compared by least significant differences (LSD, $\mathrm{P}=0.05$ ).

\section{Mycelial Compatible Groups}

To determine MCG variability, S. sclerotiorum and S. minor 
isolates were paired in all possible combinations according to Kohn et al. (1991). Agar disc at $5 \mathrm{~mm}$ in diameter from three-day PDA culture of the each isolate was placed on PDA medium, three pairing per dish and incubated in the dark at room temperature. The formation of a barrage zone was assumed as the evidence of incompatible between different isolates while the formation of a confluent mycelium, and the uniform distribution of sclerotia were assessed as mycelial compatibility (Fig. 1).

\section{Results}

A total of 106 isolates were collected from different fields in Ankara province, providing approximately $92 \%$ of Turkey's Jerusalem artichoke production. Among the fungi species identified, Sclerotinia spp. were detected as the most common wilt/rot pathogen. Based on morphological and cultural characteristics, sixty-four isolates were identified as $S$. minor while twenty-nine isolates belonged to $S$. sclerotiorum. Sclerotia of $S$. minor were black, irregular, spherical or elliptical and $0.7-1.6 \mathrm{~mm}$ in length. $S$. sclerotiorum produced black sclerotia ranging from 6.2 to $12.5 \mathrm{~mm}$ in length. Seven isolates were assigned to the species $M$. phaseolina, producing black, oblong to round sclerotia with mycelial appendages. Six isolates were classified as Fusarium oxysporum (3 isolates) and $F$. equiseti (3 isolates). Also, the symptoms of powdery mildew disease were observed on the surface of the leaves in some areas, although it was not common. The pathogen was classified into $G$. cichoracearum based on microscopic structures. Conidiophores were single on a hyphal cell, measured 112.5-195 $\times$ 10-12.5 $\mu \mathrm{m}$ and produced 2-6 immature conidia in chains with a sinuate outline. Conidia were ellipsoid-ovoid, measured 30-41.2 x 16.2-23.7 $\mu \mathrm{m}$, and without fibrosin bodies.

Morphological identification of the isolates was also confirmed by species-specific PCR assays and DNA sequencing analysis. The identification of Sclerotinia spp. was performed using species-specific primers, designed for novel laccase gen (Hirschhäuser and Fröhlich, 2007). The primer MP-SmF/MP-UniR amplified the expected 835 bp DNA fragment from $S$. minor while the primer MP$\mathrm{SsF} / \mathrm{MP}-U$ niR gave the specific fragment of $632 \mathrm{bp}$ from $S$. sclerotiorum. BLAST analysis of ITS region of $M$. phaseolina, S. minor, $F$. oxysporum and $F$. equiseti showed high level of genetic similarity with DNA sequences of fungi species available in GenBank. ITS region of powdery mildew examined by BLAST showed $100 \%$ sequence homology with $G$. cichoracearum isolates in Genbank. The resulting sequences from $M$. phaseolina, $G$. cichoracearum and $S$. minor were deposited in GenBank under accession number KF453967, KF453969 and KF453970, respectively.

Pathogenicity tests showed that $M$. phaseolina, $S$. minor and $S$. sclerotiorum were highly pathogenic to Jerusalem artichoke under controlled conditions. $M$. phaseolina caused typical charcoal rot symptoms, including silvery gray coloration of stems at the soil surface and black, spherical microsclerotia in the pith area of infected stems. $S$. sclerotiorum and $S$. minor isolates tested for pathogenicity showed significant variation in their ability to infect and spread on stem $(\mathrm{P}=0.05)$. S. sclerotiorum isolates were observed to be more pathogenic than $S$. minor isolates. Pathogenic variability among $S$. sclerotiorum isolates ranged 3 to 11.57 (Table 1), while isolates of $S$. minor caused lesion sizes, ranging 1.87 to 8.17 (Table 2). However, isolates of $F$. oxysporum and $F$. equiseti did not cause visible symptoms on Jerusalem artichoke plants and were classified as non-pathogenic.

Mycelial compatibility testing was performed among 29 S. sclerotiorum and 64 S. minor isolates (Fig. 1). All the isolates were compatible within themselves. Among $S$. sclerotiorum isolates studied, 16 MCGs were identified, out of those nine were represented by single isolates (Table 1). MCG 2, 6 and 12 consisted of four isolates while MCG 7, 11, 13 and 16 included two isolates. Seven MCGs were identified within $S$. minor population (Table 2). MCG 3 was the most common group with 21 isolates, followed by MCG 2 with 18 isolates. MCG 1 consisted of 10 isolates while MCG 4, 5, 6 and 7 included 8, 5, 1 and 1 isolates, respectively.

\section{Discussion}

For determining fungal pathogens associated with Jerusalem artichoke production of Turkey, isolates from collected disease samples were identified as $S$. minor, S. sclerotiorum, M. phaseolina, $G$. cichoracearum, $F$. oxysporum and $F$. equiseti based on morphological characteristics, DNA sequencing and species-specific PCR assay. All isolates were pathogenic to Jerusalem artichoke except for the isolates of $F$. oxysporum and $F$. equiseti. To our knowledge, this is the first reports of $S$. minor, M. phaseolina, $G$. cichoracearum in this crop in Turkey. Similarly, S. minor, $M$. phaseolina and $G$. cichoracearum were reported to be pathogenic to Jerusalem artichoke by different researchers (McCarter and Kays, 1984; Gulya and Masirevic, 1991; Koike et al., 2007).

Jerusalem artichoke has been widely used as gene source for breeding resistance into sunflower (Kays and Nottingham, 2007). Both species are infected by similar fungal pathogens. Sclerotinia wilt/rot caused by $S$. minor and $S$. sclerotiorum is recorded as the most important disease of Jerusalem artichoke in the world (Koike et al., 2007). Our results showed that all production areas were infected with Sclerotinia wilt/rot pathogens. S. minor was found as the most common species in this crop, followed by $S$. sclerotiorum. Thus, pathogenic and genetic variations within Sclerotinia populations were further characterized. Pathogenicity tests revealed significant variation in their aggressiveness. S. sclerotiorum isolates were detected to be more virulent than $S$. minor isolates in this region in agreement to the results of Tozlu 
Özer and Bayraktar / Int. J. Agric. Biol., Vol. 17, No. 3, 2015

Table 1: Mycelial compatibility groups and pathogenic variability within Sclerotinia sclerotiorum population obtained from Jerusalem artichoke plants in Ankara province

\begin{tabular}{|c|c|c|c|c|c|c|c|}
\hline Isolates & Location & MCGs & Lesion size $(\mathrm{cm})$ & Isolates & Location & MCGs & Lesion size $(\mathrm{cm})$ \\
\hline JaSs-01 & Beypazarı-Başören & 1 & 5.03 & JaSs-16 & Beypazarı-Başören & 10 & 4.03 \\
\hline JaSs-02 & Beypazarı-Başören & 2 & 6.63 & JaSs-17 & Beypazarı-Gürağaç & 6 & 4.10 \\
\hline JaSs-03 & Beypazarı-Başören & 2 & 6.50 & JaSs-18 & Beypazarı-Gürağaç & 11 & 8.37 \\
\hline JaSs-04 & Beypazarı-Başören & 2 & 3.70 & JaSs-19 & Beypazarı-Gürağaç & 11 & 3.80 \\
\hline JaSs-05 & Beypazarı-Başören & 2 & 6.03 & JaSs-20 & Beypazarı-Gürağaç & 12 & 9.47 \\
\hline JaSs-06 & Beypazarı-Başören & 3 & 6.33 & JaSs-21 & Beypazarı-Gürağaç & 12 & 9.17 \\
\hline JaSs-07 & Beypazarı-Başören & 4 & 5.87 & JaSs-22 & Beypazarı-Gürağaç & 12 & 11.57 \\
\hline JaSs-08 & Beypazarı-Başören & 5 & 5.47 & JaSs-23 & Beypazarı-Gürağaç & 12 & 6.73 \\
\hline JaSs-09 & Beypazarı-Başören & 6 & 7.27 & JaSs-24 & Beypazarı-Bağözü & 13 & 3.00 \\
\hline JaSs-10 & Beypazarı-Başören & 7 & 7.30 & JaSs-25 & Beypazarı-Bağözü & 14 & 6.23 \\
\hline JaSs-11 & Beypazanı-Başören & 7 & 3.63 & JaSs-26 & Beypazarı-Bağözü & 15 & 5.10 \\
\hline JaSs-12 & Beypazarı-Başören & 8 & 7.00 & JaSs-27 & Beypazarı-Bağözü & 13 & 9.30 \\
\hline JaSs-13 & Beypazarı-Başören & 6 & 8.17 & JaSs-28 & Nallıhan-Davutoğlan & 16 & 6.70 \\
\hline JaSs-14 & Beypazarı-Başören & 6 & 7.00 & JaSs-29 & Nallıhan-Davutoğlan & 16 & 5.73 \\
\hline JaSs-15 & Beypazarı-Başören & 9 & 8.23 & & & & \\
\hline $\operatorname{LSD}(\mathrm{P}=0.05)$ & & & 1.46 & & & & \\
\hline
\end{tabular}

Table 2: Mycelial compatibility groups and pathogenic variability within Sclerotinia minor population obtained from Jerusalem artichoke plants in Ankara province

\begin{tabular}{|c|c|c|c|c|c|c|c|}
\hline Isolate & Location & MCGs & Lesion size $(\mathrm{cm})$ & Isolate & Location & MCGs & Lesion size $(\mathrm{cm})$ \\
\hline$\overline{\mathrm{JaSm}-01}$ & Beypazar1-Başören & 1 & 6.67 & JaSm-33 & Beypazar1-Gürağaç & 5 & 5.13 \\
\hline JaSm-02 & Beypazarı-Başören & 1 & 5.83 & $\mathrm{JaSm}-34$ & Beypazarı-Gürağaç & 2 & 4.40 \\
\hline JaSm-03 & Beypazarı-Başören & 1 & 5.37 & JaSm-35 & Beypazarı-Gürağaç & 5 & 7.47 \\
\hline JaSm-04 & Beypazarı-Başören & 2 & 5.97 & JaSm-36 & Beypazan-Gürağaç & 3 & 7.13 \\
\hline JaSm-05 & Beypazarı-Başören & 1 & 5.97 & JaSm-37 & Beypazarı-Gürağaç & 5 & 7.00 \\
\hline JaSm-06 & Beypazarı-Başören & 1 & 6.77 & JaSm-38 & Beypazanı-Gürağaç & 3 & 7.10 \\
\hline JaSm-07 & Beypazarı-Başören & 1 & 6.20 & JaSm-39 & Beypazan-Gürağaç & 3 & 7.67 \\
\hline JaSm-08 & Beypazarı-Başören & 1 & 4.50 & $\mathrm{JaSm}-40$ & Beypazarı-Gürağaç & 4 & 4.77 \\
\hline JaSm-09 & Beypazarı-Bağözü & 2 & 7.63 & $\mathrm{JaSm}-41$ & Beypazarı-Gürağaç & 3 & 6.50 \\
\hline JaSm-10 & Beypazarı-Bağözü & 2 & 2.77 & JaSm-42 & Beypazan1-Gürağaç & 6 & 5.10 \\
\hline JaSm-11 & Beypazan-Bağözü & 2 & 2.13 & $\mathrm{JaSm}-43$ & Beypazarı-Gürağaç & 2 & 4.77 \\
\hline JaSm-12 & Beypazarı-Bağözü & 2 & 6.63 & $\mathrm{JaSm}-44$ & Beypazarı-Gürağaç & 4 & 2.90 \\
\hline JaSm-13 & Beypazan1-Bağözü & 2 & 1.87 & $\mathrm{JaSm}-45$ & Beypazarı-Gürağaç & 4 & 7.07 \\
\hline JaSm-14 & Beypazan1-Bağözü & 2 & 6.27 & JaSm-46 & Beypazar1-Bağözü & 2 & 4.50 \\
\hline JaSm-15 & Beypazarı-Bağözü & 3 & 7.13 & $\mathrm{JaSm}-47$ & Beypazarı-Bağözü & 2 & 5.93 \\
\hline JaSm-16 & Beypazarı-Bağözü & 3 & 5.50 & JaSm-48 & Beypazarı-Bağözü & 2 & 6.57 \\
\hline JaSm-17 & Beypazarı-Gürağaç & 4 & 6.20 & JaSm-49 & Beypazar1-Bağözü & 4 & 2.23 \\
\hline JaSm-18 & Beypazan-Gürağaç & 4 & 2.13 & $\mathrm{JaSm}-50$ & Beypazar1-Bağözü & 2 & 5.00 \\
\hline JaSm-19 & Beypazarı-Gürağaç & 3 & 2.27 & JaSm-51 & Beypazarı-Bağözü & 3 & 2.00 \\
\hline JaSm-20 & Beypazarı-Gürağaç & 4 & 6.87 & $\mathrm{JaSm}-52$ & Beypazarı-Bağözü & 7 & 3.77 \\
\hline JaSm-21 & Beypazanı-Gürağaç & 4 & 4.47 & $\mathrm{JaSm}-53$ & Beypazarı-Bağözü & 3 & 7.17 \\
\hline JaSm-22 & Beypazarı-Gürağaç & 3 & 8.17 & $\mathrm{JaSm}-54$ & Beypazarı-Bağözü & 3 & 3.77 \\
\hline JaSm-23 & Beypazarı-Gürağaç & 3 & 4.43 & JaSm-55 & Beypazarı-Bağözü & 3 & 3.10 \\
\hline JaSm-24 & Beypazarı-Gürağaç & 1 & 7.03 & JaSm-56 & Beypazar1-Bağözü & 3 & 2.47 \\
\hline JaSm-25 & Beypazan-Gürağaç & 1 & 6.93 & $\mathrm{JaSm}-57$ & Beypazar1-Bağözü & 3 & 3.83 \\
\hline JaSm-26 & Beypazarı-Gürağaç & 3 & 4.03 & JaSm-58 & Beypazar1-Bağözü & 3 & 6.03 \\
\hline JaSm-27 & Beypazarı-Gürağaç & 3 & 6.27 & JaSm-59 & Beypazarı-Başağaç & 2 & 6.53 \\
\hline $\mathrm{JaSm}-28$ & Beypazan-Gürağaç & 1 & 6.50 & JaSm-60 & Beypazarı-Başağaç & 2 & 4.50 \\
\hline JaSm-29 & Beypazarı-Gürağaç & 3 & 2.13 & JaSm-61 & Beypazanı-Başağaç & 2 & 6.23 \\
\hline $\mathrm{JaSm}-30$ & Beypazan-Gürağaç & 3 & 6.27 & JaSm-62 & Beypazar1-Kuyucak & 2 & 2.87 \\
\hline JaSm-31 & Beypazar1-Gürağaç & 5 & 7.30 & JaSm-63 & Beypazar1-Kuyucak & 2 & 3.33 \\
\hline JaSm-32 & Beypazarı-Gürağaç & 5 & 7.30 & JaSm-64 & Beypazar1-Kuyucak & 3 & 6.97 \\
\hline $\operatorname{LSD}(\mathrm{P}=0.05)$ & & & 1.01 & & & & \\
\hline
\end{tabular}

and Demirci (2008) reported that $S$. sclerotiorum was more aggressive than $S$. minor on different sunflower cultivars. However, S. sclerotiorum was found as more common than $S$. minor in the previous studies associated with sunflower in contrast to the results of this study showed that S. minor comprised $60.4 \%$ of all the isolates. Demirci and Kordalı (1998) identified 90.3\% $S$. sclerotiorum and $9.7 \%$ S. minor among Sclerotinia spp. associated with sunflower in Pasinler plain, Erzurum province. Tozlu and Demirci (2008) identified 73\% S. sclerotiorum and $27 \%$ S. minor of Sclerotinia spp. from sunflower fields in the same province. Also, different sunflower cultivars showed significant variation in their sensitivity to these pathogens. Differences in the 

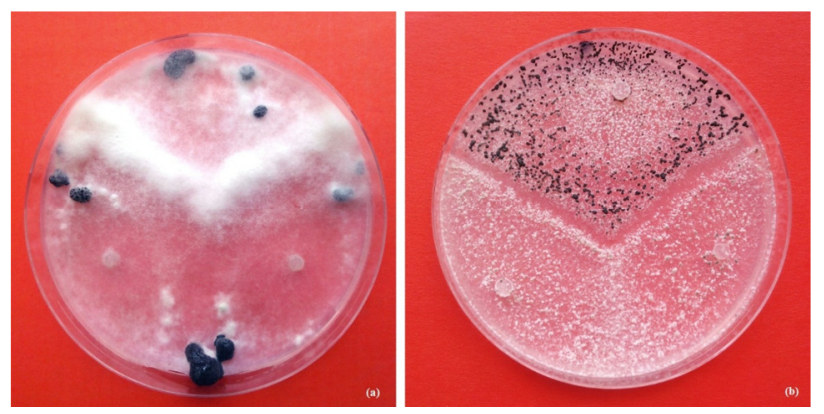

Fig. 1: Mycelial compatibility and incompatibility reactions among different Sclerotinia sclerotiorum (a) and Sclerotinia minor $(\mathrm{b})$ isolates

prevalence of S. minor and S. sclerotiorum populations were observed in lettuce fields in different geographical locations of California (Wu and Subbarao, 2006). Similar pathogenic variations within $S$. sclerotiorum populations were detected in sunflower by different researchers (Degener et al., 1999; Ziqin et al., 2008; Irani et al., 2011).

Mycelial compatibility grouping has been widely used to assess genetic variation within the populations of Sclerotinia spp. (Kohn et al., 1990; Wu and Subbarao, 2006; Yanar and Onaran, 2011). However, there were no reports about the compatibility groups of $S$. sclerotiorum and $S$. minor associated with wilt/rot disease of Jerusalem artichoke. The results indicated a high level of MCG diversity within both the pathogen populations in each locality. MCG diversity occurred independently from pathogenic variability of $S$. sclerotiorum and $S$. minor isolates. High and low virulent isolates were included in the same group. These results were in consistent with those of Tozlu and Demirci (2008) who detected nine MCGs among the 68 isolates of $S$. sclerotiorum from sunflower in Turkey. Irani et al. (2011) found 26 MCGs among $186 \mathrm{~S}$. sclerotiorum isolates collected from sunflower fields in different provinces of Iran. Kull et al. (2004) identified 42 MCGs among 299 S. sclerotiorum isolates and detected low level of correlation between MCG frequency and the aggressiveness of the isolates. Similarly, high level of MCG diversity within $S$. sclerotiorum populations was observed on canola, potato and chickpea (Atallah et al., 2004; Akram et al., 2008; Karimi et al., 2012). S. minor isolates were classified into 7 MCGs, only two of those consisted of one isolate. Wu and Subbarao (2006) detected 23 different MCGs within $S$. minor populations, causing lettuce drop in California, $91.4 \%$ of total isolates belonged to 4 MCGs. However, Tozlu and Demirci (2008) tested S. minor isolates from sunflower for MCGs on Patterson's medium containing red food coloring, but not observed barage zone among the isolates. Similarly, MCGs could not be detected among $S$. minor isolates from lettuce (Mert-Türk and Mermer, 2004). The standard medium containing high level of McCormick's red food coloring may be inhibit compatibility between the isolates from the same population (Schafer and Kohn, 2006).

\section{Conclusion}

Fungal pathogens associated with the Jerusalem artichoke production of Turkey were characterized in detail for the first time. High level of pathogenic and MCGs variability was observed between the isolates of $S$. sclerotiorum and $S$. minor, the most important pathogens in Jerusalem artichoke fields. The sexual recombination and genetic exchanges occur frequently in these pathogen populations in this region. These results should be taken into consideration in developing disease management programs to control these pathogens.

\section{References}

Agrios, G.N., 2005. Plant Pathology, p: 922. Burlington, MA: Elsevier Academic Press, New York, USA

Akram, A., S.H.M. Iqbal, N. Ahmed, U. Iqbal and A. Ghafoor, 2008. Morphological variability and mycelial compatibility among the isolates of Sclerotinia sclerotiorum associated with stem rot of chickpea. Pak. J. Bot., 40: 2663-2668

Atallah, Z.K., B. Larget, X. Chen and D.A. Johnson, 2004. High genetic diversity, phenotypic uniformity, and evidence of outcrossing in Sclerotinia sclerotiorum in the Columbia Basin of Washington State. Phytopathology, 94: 737-742

Braun, U., 1987. A monograph of the Erysiphales (powdery mildews). Nova Hedwigia Beihefte, 89: 1-700

Bremer, H., 1954. Türkiye Fitopatolojisi Cilt 3 Bahçe Kültürleri Hastalıkları, Vol. 715, p: 295. Çeviren: M. Özkan. Ziraat Vekaleti Neşriyat ve Haberleşme Müdürlüğü, Ankara İstiklal Matbaası, Turkey

Cho, S.E., M.J. Park, J.H. Park, K.S. Han and H.D. Shin, 2012. First report of Golovinomyces cichoracearum associated with powdery mildew on Helianthus tuberosus in Korea. Aust. Plant Dis. Notes, 7 : $35-37$

Degener, J.A., E. Melchinger and V. Hahn, 1999. Optimal allocation of resources in evaluating current sunflower inbred lines for resistance to Sclerotinia. Plant Breed., 118: 157-160

Demirci, E. and S. Kordal1, 1998. Fungi determined on sunflower in Pasinler plain, Erzurum, pp: 314-317. Türkiye VIII. Fitopatoloji Kongresi Bildirileri, Ankara

Domsch, K.H., W. Gams and T.H. Anderson, 1980. Compendium of Soil Fungi, p: 859. Acad. Press, London

Edel, V., C. Steinberg, N. Gautheron and C. Alabouvette, 2000. Ribosomal DNA-targeted oligonucleotide probe and PCR assay specific for Fusarium oxysporum. Mycol. Res., 104: 518-526

Gulya, T.J. and S. Masirevic, 1991. Common names for plant diseases: sunflower (Helianthus annuus L.) and Jerusalem artichoke (Helianthus tuberosus L.). Plant Dis., 75: 230

Hirschhäuser, S. and J. Fröhlich, 2007. Multiplex PCR for species discrimination of Sclerotiniaceae by novel laccase introns. Int. J. Food Microbiol., 118: 151-157

Irani, H., A. Heydari, M. Javan-Nikkhah and A.Ş. Ibrahimov, 2011. Pathogenicity variation and mycelial compatibility groups in Sclerotinia sclerotiorum. J. Plant Prot. Res., 51: 329-336

Karimi, E., N., Safaie and M. Shams-Bakhsh, 2012. Mycelial compatibility groupings and pathogenic diversity of Sclerotinia sclerotiorum (Lib.) de Bary populations on canola in Golestan province of Iran. J. Agric. Sci. Technol., 14: 421-434

Kays, S. and S.F. Nottingham, 2007. Biology and Chemistry of Jerusalem Artichoke: Helianthus tuberosus L. Taylor and Francis Group, Boca Raton, Florida, USA 
Kohn, L.M., I. Carbone and J.B. Anderson, 1990. Mycelial interactions in Sclerotinia sclerotioum. Exp. Mycol., 14: 255-267

Kohn, L.M., E. Stasovski, I. Carbone, J. Royer and J.B. Anderson, 1991. Mycelial incompability and molecular markers identify genetic variability in field populations of Sclerotinia sclerotiorum. Phytopathology, 81: 480-485

Koike, S.T., P. Gladders and A.O. Paulus, 2007. Vegetable Diseases: a Color Handbook, p: 448. Academic Press, London

Kull, L.S., W.L. Pedersen, D. Palmquist and G.L. Hartman, 2004. Mycelial compatibility grouping and aggressiveness of Sclerotinia sclerotiorum. Plant Dis., 88: 325-332

Kusaba, M. and T. Tsuge, 1995. Phylogeny of Alternaria fungi known to produce host-specific toxins on the basis of variation in internal transcribed spacers of ribosomal DNA. Curr. Genet., 28: 491-498

Leslie, J.F. and B.A. Summerell, 2006. The Fusarium Laboratory Manual, p: 388. Blackwell Professional, Ames, Iowa, USA

McCarter, S.M. and S.J. Kays, 1984. Diseases limiting production of Jerusalem artichokes in Georgia. Plant Dis., 68: 299-302

Mert-Türk, F. and D. Mermer, 2004. Determination of disease incidence and mycelial compatible groups of Sclerotinia sclerotiorum in lettuce growing in greenhouses of Çanakkale province. J. Agric. Fac. MKU, 9: $1-8$

Nene, Y.L. and M.P. Haware, 1980. Screening chickpea for resistance to wilt. Plant Dis., 66: 379-380

Schafer, M.R. and L.M. Kohn, 2006. An optimized method for mycelial compatibility testing in Sclerotinia sclerotiorum. Mycologia, 98 : 593-597
Tariq, V.N., C.S. Gutteridge and P. Jeffries, 1985. Comparative studies of cultural and biochemical characteristics used for distinguishing species within Sclerotinia. Trans. Brit. Mycol. Soc., 84: 381-397

Tozlu, E. and E. Demirci, 2008. Incidence and characterization of sunflower stem rot disease caused by Sclerotinia sclerotiorum and S. minor in Pasinler Plain of Erzurum, and reaction of some sunflower cultivars to the pathogens. Plant Prot. Bull., 48: 19-33

TUIK, 2013. Plant Production Statistics. Turkey Prime Ministry-Turkish Statistical Institute. web: http://www.tuik.gov.tr

White, T.J., T.D. Bruns, S. Lee and J. Taylor, 1990. Amplification and direct sequencing of fungal ribosomal genes form phylogenetics. In: PCR Protocols, 315-322. Innis, M.A., D.H. Gelfrand, J.J. Sninsky and T.J. White (eds.). Academic Press, San Diego, California, USA

Wu, B.M. and K.V. Subbarao, 2006. Analyses of lettuce drop incidence and population structure of Sclerotinia sclerotiorum and S. minor. Phytopathology, 96: 1322-1329

Yanar, Y. and A. Onaran, 2011. Mycelial compatibility groups and pathogenicity of Sclerotinia sclerotiorum (Lib.) De Bary causal agent of white mold disease of greenhouse grown cucumber in Antalya-Turkey. Afr. J. Biotechnol., 10: 3739-3746

Ziqin, L., M. Zhang, Y. Wang, R. Li and D.W.G. Fernando, 2008. Mycelial compatibility group and pathogenicity variation of $S$. sclerotiorum populations in sunflower from China, Canada and England. Plant Pathol., J., 7: 131-139

(Received 29 April 2014; Accepted 20 October 2014) 